\title{
PENGEMBANGAN E-MODULE INTERAKTIF SEBAGAI SUMBER BELAJAR PADA MATERI SISTEM PERIODIK UNSUR
}

\section{DEVELOPMENT OF INTERACTIVE E-MODULE AS LEARNING RESOURCES IN THE ELEMENTS PERIODIC SYSTEM MATERIALS}

\author{
Syahrul Wahyu Rahmatsyah dan *Kusumawati Dwiningsih \\ Jurusan Kimia FMIPA Universitas Negeri Surabaya \\ e-mail: kusumawatidwiningsih@unesa.ac.id
}

\begin{abstract}
Abstrak
Penelitian ini bertujuan untuk mengetahui kelayakan, keefektifan, dan kepraktisan media pembelajaran berbentuk e-module interaktif. Metode penelitian yang digunakan adalah Research and Development (R\&D) dengan model pengembangan 4D (Define, Design, Develop, and Dessiminate) yang dimodifikasi menjadi 3D. Instrumen yang digunakan adalah lembar telaah, validasi, angket respon, pretest, dan posttest. Data diperoleh berdasarkan hasil wawancara guru kimia dan pemberian angket terhadap peserta didik. Instrumen yang digunakan terdiri dari lembar telaah, validasi, angket respon peserta didik, tes (Pretest dan Posttest). Hasil validasi perangkat ini mendapat skor 90\% untuk kriteria isi, $93 \%$ untuk kriteria penyajian, $84 \%$ untuk kriteria kebahasaan, dan $100 \%$ untuk kriteria kegrafikan yang dapat diartikan sangat layak untuk digunakan. Kepraktisan e-module diketahui dari hasil respon peserta didik dengan rata rata skor lebih dari $81 \%$ yang dapat dikategorikan sangat merespon. E-module interaktif juga dikatakan sangat efektif dengan menganalisis hasil belajar menggunakan uji $\mathrm{t}$ dengan nilai signifikansi $5 \%$. Maka dari itu, e-module interaktif sebagai sumber belajar pada materi sistem periodik unsur dapat dijadikan solusi dari permasalahan kegiatan pembelajaran daring.
\end{abstract}

Kata kunci: e-module interaktif, sistem periodik unsur, sumber belajar

\begin{abstract}
The purpose of this research is to determine the feasibility, effectiveness, and practicality of learning media in the form of interactive e-module. The research method used is Research and Development $(R \& D)$ with a $4 D$ development model (Define, Design, Develop, and Dessiminate) which is modified into $3 D$. The instruments used consisted of review sheets, validation, student response questionnaires, tests (pretest and posttest). The data were obtained based on the results of interviews with chemistry teachers and giving questionnaires to students. The results of the validation of this device got a score of $90 \%$ for content criteria, 93\% for presentation criteria, $84 \%$ for language criteria, and $100 \%$ for graphic criteria are very feasible to use. The practicality of the e-module is known from the results of the responses of students with an average score of more than $81 \%$ which can be categorized as highly responding. The interactive e-module is also said to be very effective by analyzing learning outcomes using the t test with a significance value of 5\%. Therefore, the interactive e-module as a learning resource on the elemental periodic system material can be used as a solution to the problems of online learning activities
\end{abstract}

Keywords: interactive e-module, periodic system of elements, learning resource

\section{PENDAHULUAN}

Pendidikan adalah salah satu cara untuk memajukan dan mencerdaskan manusia terutama bangsa Indonesia. Dalam pelaksanaan pendidikan, penggunaan kurikulum tertentu menentukan arah dalam kemajuan pendidikan. Salah satunya penggunaan kurikulum 2013 yang berorientasi dalam meningkatkan keterampilan, sikap dan pengetahuan sesuai dengan pasal 35 UU No. 20 Tahun 2003 yang memuat kompetensi lulusan 
adalah kualifikasi kemampuan lulusan yang meliputi sikap, pengetahuan, dan keterampilan sesuai dengan standar nasional yang disepakati. Sehingga nilai-nilai karakter dapat diintegrasikan dalam pembelajaran [1].

Kimia adalah ilmu yang diperoleh dan dikembangkan melalui eksperimen, mencari jawaban atas pertanyaan tentang apa, mengapa, dan bagaimana fenomena alam dapat terjadi. Oleh karena itu, perlu menguasai konsep dan materi serta mengaplikasikan ilmu kimia dalam kehidupan sehari-hari [2].

Tahun 2020 digemparkan dengan maraknya virus corona (COVID-19) yang menyebabkan kekacauan di seluruh dunia. Pandemi COVID-19 juga berdampak buruk bagi negara Indonesia, mulai dari kehidupan sosial masyarakat, ekonomi, sampai pendidikan. Hal ini menjadi faktor eksternal yang mempengaruhi kegiatan belajar mengajar [3]. Keterbatasan secara fisik membuat seluruh aktivitas terbatas dan terpaksa dilakukan pembelajaran daring. Pembelajaran daring adalah bentuk kegiatan belajar mengajar yang dilakukan secara jarak jauh dengan menggunakan internet yang berfungsi untuk menghubungkan peserta didik dengan sumber belajarnya [4]. Media yang digunakan saat pembelajaran daring sangat beragam, ada yang menggunakan kelas vritual seperti Google classroom, Edmodo, sampai Whatsapp Group. Ada juga yang melalui video conference seperti zoom, google meet, microsoft teams dan lain-lain [5]. Namun, keterbatasan waktu dan kualitas jaringan membuat pembelajaran daring tidak seefektif pembelajaran tatap muka [6].

Sumber belajar merupakan faktor penting dalam meningkatkan kualitas pembelajaran. Sumber belajar meliputi pesan (semua informasi berupa ide, fakta dan data yang disampaikan kepada peserta didik), personel (orang yang berperan sebagai penyaji dan pemroses pesan, seperti guru, personel kaya sumber, dan berpartisipasi dalam kegiatan pembelajaran), materi (software), alat (hardware yang digunakan untuk menyampaikan pesan), teknologi (proses yang digunakan untuk menyajikan pesan) dan lingkungan (kondisi atau keadaan di mana kegiatan pembelajaran terjadi) [7].

SMAN 15 Surabaya merupakan salah satu sekolah di Surabaya yang menerapkan pembelajaran daring melalui Microsoft Teams. Beberapa peserta didik di SMAN 15 mengalami kesulitan dalam memahami materi kimia salah satunya adalah materi sistem periodik unsur. Materi sistem periodik unsur tidak dapat dipelajari 2-3 kali tatap muka, karena terdapat pemahaman yang komplek, yaitu sub bab konfigurasi elektron dan bilangan kuantum [8]. Oleh karena itu, penggunaan media pembelajaran e-module sebagai sumber belajar adalah solusi yang tepat untuk mengatasi masalah tersebut.

Modul elektronik atau biasa disebut dengan electronic module (e-module) merupakan seperangkat media pembelajaran digital non cetak yang dirangkai secara sistematis dan dapat digunakan secara mandiri oleh peserta didik sehingga memecahkan masalah dengan caranya sendiri [9]. E-module sendiri memiliki keunggulan yang praktis, daya tahan yang lama, dan biaya produksi lebih murah dibanding modul cetak pada umunya [10]. E-module memiliki jenis yang beragam, salah satumya bersifat interaktif. Keunggulan e-module interaktif adalah sifatnya yang interaktif, memudahkan dalam navigasi, dan menampilkan gambar, audio, video animasi serta dilengkapi tes/kuis yang memberikan efek timbal balik secara otomatis [11]. E-module interaktif dapat digunakan sebagai sumber belajar saat pembelajaran daring karena bersifat offline, dimana peserta didik dapat mengunduh e-module kemudian dioperasikan pada Personal Computer (PC) atau laptop pribadi yang dapat diakses kapanpun dan dimanapun.

Berdasarkan latar belakang diatas, peneliti ingin mengembangkan $e$-module interaktif sebagai sumber belajar pada materi sistem periodik unsur sebagai solusi dari permasalahan pada kegiatan pembelajaran daring di era pandemi.

\section{METODE}

Jenis penelitian yang digunakan adalah Research and Development (R\&D). Metode R\&D adalah suatu proses menciptakan produk baru atau 
meningkatkan produk yang sudah ada di mana semua tindakannya dapat dibenarkan [11]. Model pengembangan yang digunakan adalah model 4-D yang terdiri dari 4 tahap yaitu define (pendefinisian), design (perancangan), develop (pengembangan) dan disseminate (penyebaran) yang dimodifikasi menjadi 3-D [12]. Penelitian ini tidak dilakukan sampai tahap disseminate karena tujuan penelitian hanya sampai uji coba e-module interaktif yang dikembangkan [13].

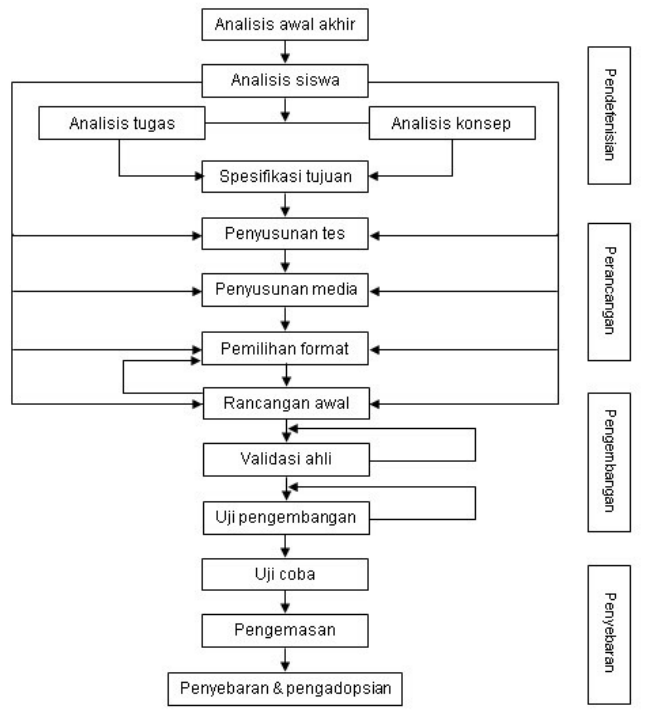

Gambar 1. Model Pengembangan 4-D

Pelaksanaan penelitian dimulai dari tahap define (pendefinisian), yaitu menganalisis kegiatan pembelajaran daring secara terbatas akibat pandemi Covid-19. Analisis dilakukan dengan wawancara terhadap salah satu guru kimia di SMAN 15 Surabaya dan menetapkan permasalahan antara guru dengan peserta didik dalam kegiatan belajar mengajar. Analisis yang kedua dilakukan terhadap peserta didik, dengan memberikan angket mengenai hambatan yang dialami dan sumber belajar yang digunakan pada saat pembelajaran daring.

Tahap kedua yaitu design (perancangan) yang bertujuan untuk merancang media pembelajaran yang sesuai terhadap hasil analisis pada tahap define agar dihasilkan produk yang layak untuk digunakan sebagai sumber belajar. Tahap ini diawali dengan penyusunan materi berdasarkan KD esensial yang digunakan pada saat pandemi. Langkah kedua yaitu pemilihan media pembelajaran yang sesuai dengan tahap define yakni e-module interaktif pada materi sistem periodik unsur. Kemudian pemilihan format $e$ module dengan mendesain atau merancang storyboard terlebih dahulu.

Tahap terakhir yaitu develop (pengembangan) yang bertujuan untuk menghasilkan e-module interaktif yang valid dan layak digunakan sebagai sumber belajar melalui telaah dan validasi dari validator yakni dosen dan guru kimia .

Langkah-langkah yang dilakukan saat proses validasi adalah membuat instrumen validasi yang terdiri dari validasi isi dan konstruk. Lembar validasi digunakan untuk mengetahui nilai produk yang akan dikembangkan sesuai dengan skala likert yang disajikan pada Tabel 1,

Tabel 1. Skala Likert

\begin{tabular}{cc}
\hline Pernyataan & Skor \\
\hline Tidak valid & 1 \\
Kurang valid & 2 \\
Cukup valid & 3 \\
Valid & 4 \\
Sangat valid & 5 \\
\hline
\end{tabular}

Data yang diperoleh dari validator merupakan data ordinal. Data ordinal adalah data kualitatif yang akan dinilai dengan pemberian skor terhadap kategori untuk tiap tiap item nya [16]. Analisis lebih lanjut dibutuhkan data dengan skala interval, dimana data ordinal harus ditransformasikan terlebih dahulu [17]. Data dianalisis menggunakan Method of Summated Ratings (MSR) sehingga memperoleh presentase kevalidan dengan rumus:

$(\%)$ validitas $=\frac{\text { total jumlah skor }}{\text { jumlah validator }} \times 100 \%$

Hasil persentase yang didapatkan diinterpretasikan ke dalam kriteria skor yang disajikan pada Tabel 2 .

Tabel 2. Kriteria Presentase Kevalidan

\begin{tabular}{cc}
\hline Presentase (\%) & Skor \\
\hline $0-20$ & Sangat Kurang \\
$21-40$ & Kurang \\
$41-60$ & Cukup \\
$61-80$ & Valid \\
$81-100$ & Sangat Valid \\
\hline
\end{tabular}


Berdasarkan kriteria tersebut, e-module dikatakan valid apabila semua aspek persentasenya $\geq 61 \%$ [15].

\section{HASIL DAN PEMBAHASAN}

Penelitian ini menghasilkan e-module interaktif yang didalamnya terdiri dari materi tiap sub-bab, video pembelajaran, rangkuman dan latihan soal di setiap akhir materi tiap sub bab nya sehingga dapat digunakan sebagai sumber belajar.

\section{Tahap Pendahuluan}

Berdasarkan hasil wawancara dengan guru kimia SMAN 15 Surabaya, pembelajaran daring pada materi sistem periodik unsur sangatlah tidak efektif. Hal tersebut dikarenakan jaringan yang tidak stabil sehingga membuat peserta didik tidak paham akan materi yang diajarkan. Hasil dari pemberian angket terhadap 20 peserta didik, 70\% nya masih mengalami kesulitan pada materi sistem periodik unsur saat pembelajaran dilakukan secara daring dan sumber belajar yang digunakannya. Teori belajar yang akan digunakan adalah konstruktivisme, dimana peserta didik dapat meningkatkan logika dan konseptual pembelajaran [18]

\section{Tahap Desain}

Tahap ini diawali dengan penyusunan materi yang sesuai dengan $\mathrm{KD}$ esensial, dimana materi sistem periodik unsur terdapat pada KD 3.2. Materi sistem periodik dipecah menjadi 3 sub bab yakni sejarah tabel periodik, konfigurasi elektron, dan bilangan kuantum. [19] Tahap selanjutnya yaitu perancangan e-module interaktif melalui story board.

E-Module berformat .exe yang berarti hanya dapat diakses melalui Personal Computer (PC) atau Laptop. Peserta didik tidak membutuhkan internet untuk mengoperasikannya, mereka hanya perlu mengunduh file e-module sebesar $100 \mathrm{MB}$ yang akan dikirim melalui Whatsapp group atau Microsoft Teams. Melalui teori konstruktivisme, peserta didik diajak untuk mendalami pengetahuan secara bebas atau juga bisa memaknainya sesuai pengalaman [18].

E-module diketik menggunakan aplikasi Microsoft Word 2019. Bagian utama e-module terdiri dari pemetaan kompetensi dasar, petunjuk penggunaan e-module, isi materi, video pembelajaraan, rangkuman, latihan soal, dan daftar pustaka [20]. Desain cover dan template tiap halaman, di rancang menggunakan aplikasi Corel Draw 2020.

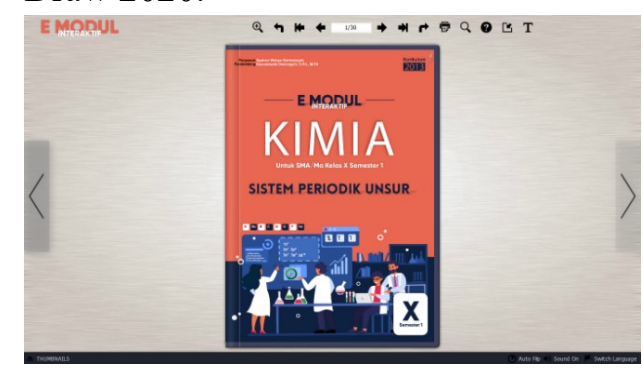

Gambar 2. Cover E-Module

Gambar 2. menampilkan tampilan awal setelah membuka file e-module interaktif, peserta didik langsung disajikan dengan cover e-module, tak hanya itu peserta didik juga disajikan tombol navigasi yang ada di atas halaman e-module interaktif. Tombol navigasi terdiri dari zoom in, zoom out, previous page, next page, halaman yang akan dituju, print, search, help, dan select text.

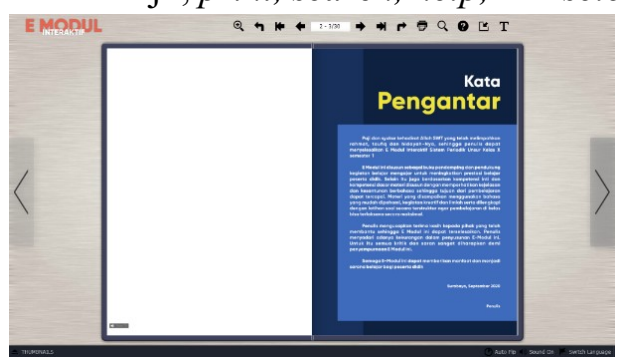

Gambar 3. Kata Pengantar

Setelah membuka cover, peserta didik akan dihadirkan dengan suara pembuka "Selamat datang di e-module Interaktif kimia kelas 10" beserta kata pengantar seperti yang disajikan pada Gambar 3.

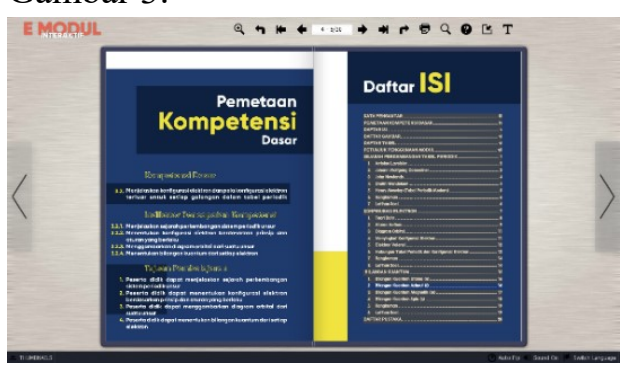

Gambar 4. Pemetaan KD dan Daftar Isi

Gambar 4. menampilkan pemetaan kompetensi dasar yang berisi kompetensi dasar, indikator pencapaian kompetensi, dan tujuan pembelajaran. Kemudian pada halaman 
selanjutnya ditampilkan daftar isi, yang dapat di klik untuk menuju ke halaman yang dituju.

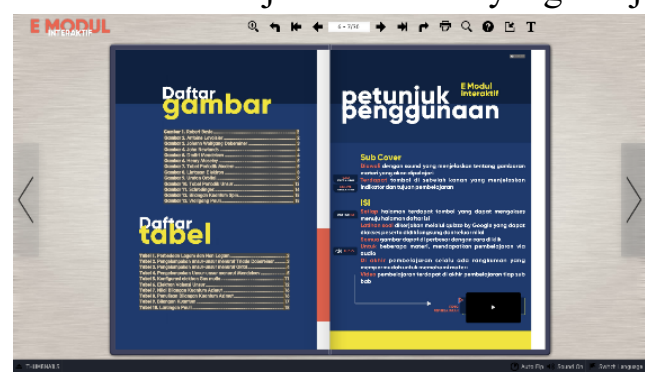

Gambar 5. Petunjuk Penggunaan E-Module

Gambar 5. menampilkan daftar gambar dan daftar tabel yang bisa di klik ke tabel atau gambar yang akan kita tuju. Halaman selanjutnya menampilkan petunjuk penggunaan e-module, disini peserta didik akan diarahkan bagaimana cara mengoperasikan e-module, karena setiap komponen yang ada di dalamnya dapat di klik dan memberikan efek timbal balik seperti tombol, gambar, dan video pembelajaran.

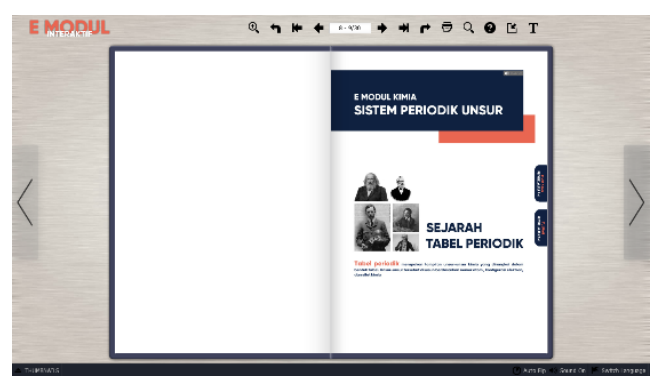

Gambar 6. Cover Tiap Sub Bab

Gambar 6. menampilkan cover sub bab yang terdapat di tiap-tiap sub bab nya, dimulai dari perkembangan sejarah tabel periodik, konfigurasi elektron dan bilangan kuantum. Peserta didik akan mendengarkan audio terkait gambaran materi tersebut secara otomatis. Tombol indikator dan tujuan pembelajaran juga dapat di klik yang akan menampilkan indikator dan tujuan pembelajaran dari materi tersebut.

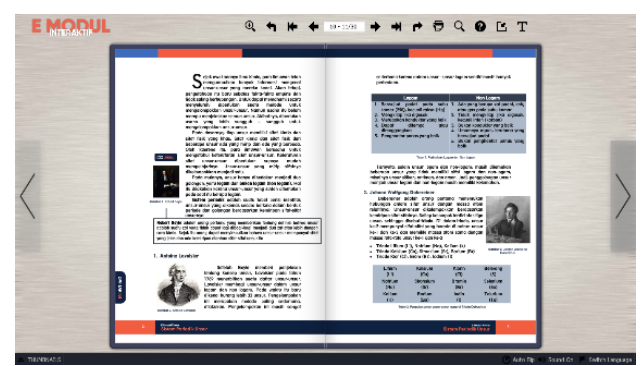

Gambar 7. Isi E-Module

Gambar 7. menampilkan isi materi secara detail dengan disertai gambar yang dapat diperbesar dengan cara di klik. Tidak hanya itu, beberapa materi juga terdapat audio yang berisi penjelasan singkat.

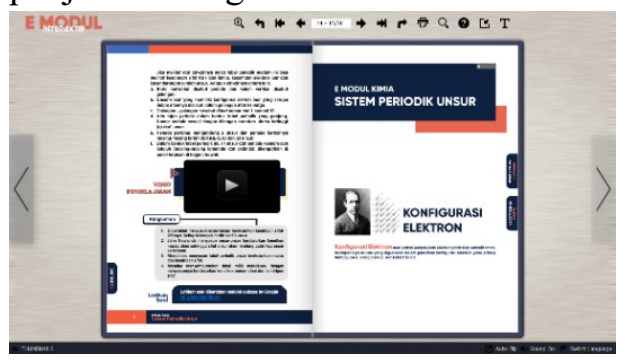

Gambar 8. Video Pembelajaran

Gambar 8. menampilkan berbagai macam komponen mulai dari video pembelajaran dalam bentuk thumbnail, yang artinya dapat di perbesar seukuran layar. Kemudian terdapat rangkuman materi yang disajikan di tiap akhir materi. Komponen yang terakhir adalah latihan soal. Latihan soal diberikan guna untuk mengasah kemampuan peserta didik yang dikemas dalam bentuk link yang terhubung ke google form. Ketiga komponen tersebut berada di halaman terakhir tiap sub bab nya.

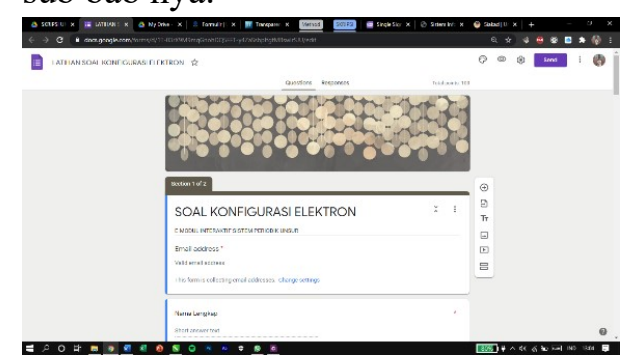

Gambar 9. Latihan Soal

Gambar 9. menampilkan latihan soal dalam bentuk Google form yang dapat dikerjakan dan langsung mendapatkan timbal balik berupa skor. Peserta didik akan diberikan 10 soal pilihan ganda tiap sub bab nya, yang sesuai dengan ranah kognitif yakni C3 dan C4 dengan waktu yang tidak dibatasi [21].

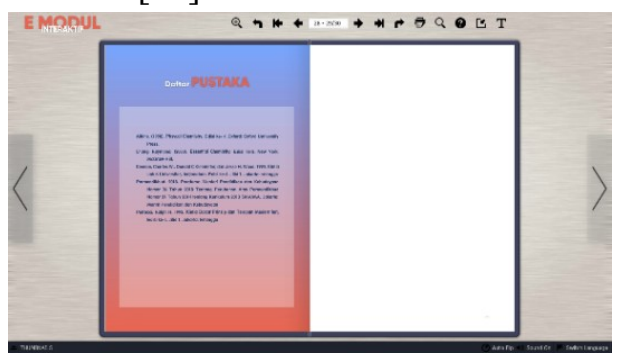

Gambar 10. Daftar Pustaka

Gambar 10. menampilkan daftar pustaka dari e-module interaktif kimia. 


\section{Tahap Pengembangan}

Tahap ini dilakukan dengan membuat instrumen validasi terlebih dahulu untuk menguji kelayakan dari e-module ini. Setelah instrumen validasi disusun, selanjutnya akan dilakukan penilaian oleh validator yakni 2 orang dosen dari jurusan kimia dan 1 orang guru kimia SMAN 15 Surabaya. Lembar validasi berisi kriteria isi, penyajian, kebahasaan dan kegrafikan. Data akhir yang diperoleh dari ketiga validator tersebut disajikan dalam Tabel 3.

Tabel 3. Hasil Validasi

\begin{tabular}{ccc}
\hline $\begin{array}{c}\text { Kriteria } \\
\text { yang Dinilai }\end{array}$ & $\begin{array}{c}\text { Presentase } \\
\text { Rata-Rata }(\%)\end{array}$ & Kategori \\
\hline Isi & 90 & Sangat Valid \\
Penyajian & 93 & Sangat Valid \\
Bahasa & 84 & Sangat Valid \\
Grafik & 100 & Sangat Valid \\
\hline
\end{tabular}

Data dari Tabel 3. diurai menurut kategori dari instrumen validasi, mulai dari kriteria isi yang memperoleh presentase $90 \%$, kriteria penyajian 93\%, kriteria kebahasaan dengan skor terendah $83 \%$, dan kriteria kegrafikan dengan skor tertinggi $100 \%$. Dari data tersebut dapat disimpulkan bahwa media pembelajaran ini valid dengan skor $\geq 61$ tiap kriteria serta kesesuaian materi dengan standar kompetensi dan kompetensi dasar [22].

Tahap selanjutnya adalah uji coba. Uji coba dilakukan untuk mengetahui kepraktisan dan keefektifan e-module interaktif ini. Kepraktisan terhadap e-module interaktif dapat diukur melalui angket respon dan aktivitas peserta didik. Angket respon diberikan kepada 20 peserta didik yang telah menggunakan e-module interaktif. Aktivitas peserta didik diamati oleh 3 mahasiswa kimia melalui Microsoft Teams. Data hasil respon peserta didik sebagai berikut.

Tabel 4. Hasil Angket Respon Peserta Didik

\begin{tabular}{ccc}
\hline $\begin{array}{c}\text { Kriteria } \\
\text { yang Dinilai }\end{array}$ & $\begin{array}{c}\text { Presentase } \\
\text { Rata-rata (\%) }\end{array}$ & Kategori \\
\hline Isi & 96 & Sangat merespon \\
Penyajian & 98 & Sangat merespon \\
Kebahasaan & 100 & Sangat merespon \\
Kegrafikan & 100 & Sangat merespon \\
\hline & &
\end{tabular}

Berdasarkan hasil respon peserta didik, setiap kriteria mendapat skor lebih dari $81 \%$ yang dapat dikategorikan sangat merespon. Hal ini dapat dinyatakan bahwa e-module interaktif telah memenuhi kriteria kepraktisan [22].

Tahap selanjutnya yaitu uji keefektifan $e$ module interaktif melalui lembar pretest dan posttest dengan jumlah 25 soal, dimana 10 soal pada sub materi sejarah perkembangan tabel periodik, 10 soal pada sub materi konfigurasi elektron, dan 5 soal pada sub materi bilangan kuantum. Soal yang diberikan berdimensi kognitif C3, dan C4 dengan tipe soal pilihan ganda [21].

Pretest diberikan sebelum peserta didik menerima e-module, sedangkan posttest diberikan pada saat peserta didik telah menggunakan $e$ module interaktif. Posttest yang diberikan kepada peserta didik berupa latihan soal yang tertera di akhir materi tiap sub bab nya. Pengukuran hasil belajar peserta didik diawali dengan melakukian uji normalitas yang bertujuan untuk mengetahui distribusi data nilai pretest dan posttest

Tabel 5. Uji Normalitas

\begin{tabular}{cccccc}
\hline \multicolumn{3}{c}{$\begin{array}{c}\text { Kolmogorov- } \\
\text { Smirnov }\end{array}$} & \multicolumn{3}{c}{ Shapiro-Wilk } \\
\hline & df & Sig. & Stat & df & Sig. \\
\hline Pre & 20 & $.200^{*}$ & .960 & 20 & .537 \\
\hline Post & 20 & .156 & .963 & 20 & .608 \\
\hline
\end{tabular}

Berdasarkan Tabel 5. diketahui nilai sig. untuk pretest sebesar 0,537 dan nilai sig. untuk posttest sebesar 0,608 . Hal ini dapat dikatakan bahwa nilai pretest dan posttest terdistribusi normal dalam uji Shapiro-Wilk dengan nilai sig. > 0,05 [23]. Setelah mengetahui hasil uji normalitas, maka dapat dilanjutkan uji $t$ dengan tujuan untuk mengetahui perbedaan signikfikan antara hasil nilai pretest dan posttest [23].

Tabel 6. Uji T Kenaikan Gain skor

\begin{tabular}{|c|c|c|c|c|c|c|}
\hline \multicolumn{4}{|c|}{ Paired Differences } & \multirow{3}{*}{$\mathbf{t}$} & \multirow{3}{*}{ df } & \multirow{3}{*}{ Sig } \\
\hline Std. & Std. & \multicolumn{2}{|c|}{$95 \%$} & & & \\
\hline Dev & Error & Low & Up & & & \\
\hline 12.1 & 2.7 & -42 & -30.7 & -13.4 & 19 & .000 \\
\hline
\end{tabular}

Berdasarkan Tabel 6. uji t diatas, diperoleh nilai signifikansi (2-tailed) $<0,05$, yang berarti Ho ditolak dan Ha diterima. Ho menyatakan bahwa tidak adanya perbedaan yang signifikan antara pretest dan posttest. Sedangkan Ha menyatakan adanya perbedaan yang signifikan antara pretest 
dan posttest. Berdasarkan hasil analisis uji t, emodule interaktif sebagai sumber belajar pada materi sistem periodik unsur dapat dikatakan sangat efektif dalam meningkatkan kualitas pembelajaran [22].

\section{SIMPULAN}

Berdasarkan hasil penelitian dan analisis data, dapat disimpulkan bahwa e-module interaktif ini dapat dikembangkan dengan mengacu model penelitian 4D (Define, Design, Develop, and Dessiminate). E-module interaktif ini dapat dikatakan sangat layak yang ditinjau dari skor validitas dengan masing-masing perolehan skor 90\% untuk kriteria isi, 93\% untuk kriteria penyajian, $84 \%$ untuk kriteria kebahasaan, dan $100 \%$ untuk kriteria kegrafikan. Selain itu, Emodule interaktif ini sangat praktis untuk digunakan, hal ini dibuktikan dengan hasil respon peserta didik, setiap kriteria mendapat skor $>81 \%$ yang dapat dikategorikan sangat merespon. $E$ module interaktif juga memenuhi kriteria keefektifan yang ditinjaui dari analisis hasil uji $\mathrm{t}$ kenaikan gain skor, dengan nilai signifikansi (2tailed) $0,00<0,05$. Oleh karena itu e-module interaktif sebagai sumber belajar pada materi sistem periodik unsur dapat dijadikan sebagai solusi dari permasalahan kegiatan pembelajaran daring.

\section{DAFTAR PUSTAKA}

1. Hidayat, S. 2017. Pengembangan Kurikulum Baru. Bandung: PT Remaja Rosdakarya Bandung.

2. Merra Rorita, S. U. 2018. Pengembangan Multimedia Interaktif Berbasis Mobile Learning Pokok Bahasan Perkembangan Teori Atom Mata Pelajaran Kimia Kelas $\mathrm{X}$ SMA Panjura Malang. JINOTEP, pp. 70-75.

3. Strielkowski, W. 2020. COVID-19 Pandemic and The Digital Revolution in Academia and Higher Education. Preprints, (April), $1-6$.
4. Kuntarto, E. 2017. Keefektifan Model Pembelajaran Daring dalam Perkuliahan Bahasa Indonesia di Perguruan Tinggi. Indonesian Language Education and Literature, Vol 3, No 1, pp. 99-110.

5. Kind, T., \& Evans, Y. 2015. Social Media for Lifelong Learning. International Review of Psychiatry, Vol 27, No 2, pp. 124-132.

6. Azmil Abidah, Hasan Nurul Hidaayatullaah, Simamora, R. M., Fehabutar, D., \& Mutakinati, L. 2020. The Impact of Covid-19 to Indonesian Education and Its Relation to the Philosophy of "Merdeka Belajar." Studies in Philosophy of Science and Education, Vol 1, No 1, pp. 38-49.

7. Novallyan, D., Gusfarenie, D., \& Safita, R. (2020). Pengembangan E-Modul Biologi Umum Berbasis Konstruktivisme Menggunakan 3D Pageflip. Jurnal Kependidikan Betara (JKB), Vol 1, No 4, pp. 152-162.

8. Dwiningsih, D. D. 2017. Pengembangan Perangkat Pembelajaran Berorientasi Blended Learning Pada Materi Sistem Periodik Unsur. UNESA Journal of Chemistry Education, pp. 16-23.

9. Hamzah, I., \& Mentari, S. 2017. Development Of Accounting E-Module To Support The Scientific Approach Of Students Grade X Vocational High School. Journal Of Accounting And Business Education, Vol 2, No 1, pp. 78-88.

10. Abdullah, S. R. 2020. Pengembangan EModule Interaktif Chemistry Magazine Berbasis Kvisoft Flipbook Maker Pada Materi Laju Reaksi. Jurnal Zarah, Vol 8, No 1, pp. 7-13.

11. Juilando, F., \& Hardeli. 2019. Validitas dan Praktikalitas E-Modul Struktur Atom Berbasis Pendekatan Saintifik pada Kelas X SMA/MA. Journal of RESIDU, Vol 3, No 14. 
12. Thiagarajan, S. Semmel, D.S \& Semuel, MI. 1974. Instructional Development for Training Teachers of Exceptional Children. Indiana: Indiana University Bloomington.

13. Syarmadi, N. I. 2020. Validitas Modul Elektronik Matematika Sebagai Bahan Berbasis Augmented Reality Ajar pada Materi Bangun Ruang Kubus dan Balok Kelas VIII SMP. Student Online Journal (SOJ), pp. 702-708.

14. Saputri, M. d. 2020. Pengembangan E-Modul Fisika Berbantuan Whatsapp Sebagai Alternatif Pemebalajaran di Masa Pandemi Covid 19. Jurnal Hasil Kajian, Inovasi, dan Aplikasi Pendidikan Fisika, pp. 213-220.

15. Riduwan. 2015. Skala Pengukuran VariabelVariabel Penelitian. Bandung: Alfabeta

16. Izzati, N. 2017. Penerapan PMR Pada Pembelajaran Matematika untuk Meningkatkan Kemandirian Belajar Siswa SMP. Jurnal Kiprah, Vol 5, No 2, pp. 30-49.

17. Waryanto, B., \& Millafati, Y. A. 2016. Transformasi Data Skala Ordinal ke Interval dengan Menggunakan Makro. Jurnal Informatika Pertanian, Vol 15, No 1, pp. 881-895.

18. Novallyan, D., Gusfarenie, D., \& Safita, R.
(2020).
Pengembangan
E-Modul
Biologi Umum
Berbasis
Konstruktivisme Menggunakan 3D
Pageflip. Jurnal Kependidikan Betara (JKB), Vol 1, No 4, pp. 152-162.

19. Kemendikbud. 2020. Kemendikbud Nomor 719/P/2020 tentang Pedoman Pelaksanaan Kurikulum pada Satuan Pendidikan dalam Kondisi Khusus pada Pendidikan Dasar dan Menengah. Jakarta: Kementrian Pendidikan dan Kebudayaan.

20. Depdiknas. 2016. Panduan Pengembangan Bahan Ajar. Jakarta: Direktorat Pembinaan Sekolah Menengah Atas Direktorat Jenderal Manajemen Pendidikan Dasar dan Menengah Departemen Pendidikan Nasional.

21. BNSP. 2010. Paradigma Pendidikan Abad XXI. Jakarta: BNSP.

22. Herawati, Nita Sunarya, and Ali Muhtadi. 2018. Pengembangan Modul Elektronik (E-Modul) Interaktif pada Mata Pelajaran Kimia Kelas XI SMA. Jurnal Inovasi Teknologi Pendidikan, Vol 5, No 2, pp. 180-91.

23. Hulu, V. T., \& Sinaga, T. R. 2019. Analisis Data Statistik Parametrik Aplikasi SPSS dan Statcal. Medan: Yayasan Kita Menulis. 